\title{
Innovation activity in the hotel industry: Evidence from Balearic Islands
}

\author{
Francina Orfila-Sintes ${ }^{\mathrm{a}}$, Rafel Crespí-Cladera ${ }^{\mathrm{a}, *}$, Ester Martínez-Ros $^{\mathrm{b}}$ \\ ${ }^{a}$ Department of Business Economics, Universitat de les Illes Balears, Cra. Valldemossa, Km. 7,5 070122 Palma de Mallorca (Islas Baleares), Spain \\ ${ }^{\mathrm{b}}$ Universidad Carlos III, Spain
}

\begin{abstract}
The paper provides empirical evidence on technological activity in the Spanish service sector, in particular for the tourist accommodation in the Balearics. The study wants to fulfil the lack of analyses in the field of tourism. Commonly, the study of innovation activity has been carried out from a manufacture perspective, for that reason the paper discusses the precise definition of innovation in accommodation services. The data refer to a large representative sample of hotels in Balearic Islands (Spain), providing a homogeneous set of information. The results show as higher categories hotels are more innovative than lower categories hotels; an aggregated measure of technological innovation presents a rate over the average for hotels that belong to a chain, and that for hotels under management contract. Half of innovative companies adjust the human capital skills and abilities. The hotel industry is a supplier driven sector that innovates introducing R\&D embodied technology rather than undertaking internal R\&D activities.
\end{abstract}

Keywords: Services innovation; Hotel industry; Balearic Islands

\section{Introduction}

The tourism sector is a high source of revenues for the Spanish Economy and accounts for 12\% of the GDP. This is a result of some structural conditions of the country that contribute to be the second European destination and the third worldwide destination by tourist arrivals, and the fourth by foreign currency income. Arrivals and income have both increased year after year in the late $90 \mathrm{~s}$ and the beginning of the 21st century. By accommodation type, $71 \%$ of the tourists (34.1 million) stayed at hotels, while the remaining stayed in rented properties and less usual types of accommodation. As for the main national destinations, the visitors place the archipelagos, the Balearic Islands and the Canary Islands, in the top position. These are

\footnotetext{
*Corresponding author. Tel.: + 34971171323 ; fax: +34971172389

E mail address: rafel.crespi@uib.es (R. Crespí Cladera).
}

two very similar attractive destinations sharing $43 \%$ of the annual Spanish arrivals (Instituto de Estudios Turísticos, 2001).

The sector is mainly in hands of private investors (Marino, 2001). When comparing the innovation activity of tourism with the figures of any manufacturing sector, nevertheless, the relevance of services innovation effort accounts only for a small proportion (in 1999, the internal R\&D expenditure was $3.8 \%$ over total services).

The statistical aggregated data available on $R \& D$ and innovation expenditures shows for Spanish figures significantly lower values than the European average. Even within Spain, there are huge differences among regions. These differences can be explained partially for the productive structure of the economy. The average intensity in R\&D investment in Spain for the year 2000 is $0.94 \%$ of the GDP. The value for a manufacturing industrial region like the Basc Country is $1.20 \%$ of the GDP and $0.25 \%$ for the Balearic Islands. The Innova tion expenses figure in relation to the GDP is $1.9 \%$ for 
the whole country, while for the Balearic Islands is $0.36 \%$ and $2.71 \%$ for the Basc Country. These patterns stay on when comparing other intensive manufacturing regions like Catalunya with the Canarias Islands, a services-oriented economy.

These figures lead us to consider to what extent the $\mathrm{R} \& \mathrm{D}$ and innovation investments are activities only for manufacturing sectors. The usual measures of innovation expenses seem to be designed for industrial economies. The aggregated statistics ${ }^{1}$ do not fit for services economies, with tourism activities as the Balearic Islands. A more detailed and accurate measure of innovation is needed for.

The issue is about to maintain the primacy and competitiveness of the tourism activity through innovation investments. The point of the paper is to investigate how technology improvements are introduced in the tourism activity companies in order to determine the current state of the art in innovation activity.

The positive evolution of the industry proves it as one of the most steady and promising sectors in the Spanish and World economy and a key strategic activity. Nevertheless, the tourism industry is a changing and dynamic businesses (WTO, 1999) and it will only keep its competitiveness adjusting to the new customers demands, adequately reacting to competitors' innovations and taking advantage of the new technological developments available in the market place (Camisón, 2000; Huybers \& Bennett, 2000; Okumus \& Hemmington, 1998). Given the lack of academic empirical research on the topic, this paper intends to be a contribution to the knowledge of the current situation of innovation in the tourism industry.

The tourism industry includes a wide range of activities such as restaurants, entertainment, transportation and accommodation. A rigorous and reliable analysis of the technological change focuses on one of these activities that include a homogeneous set of companies with similar production functions inputs, outputs and available technology and market environment. The homogeneity of the available data and the relative importance within the industry, make advisable to choose the hospitality business as the field of the study. The lodging sector is an outstanding tourist activity since is a sine qua non in the provision of all the other tourism services, being the basic requirement of the tourist at the destination point.

The Balearic Islands, a leading tourist destination (Aguilo Perez \& Juaneda Sampol, 2000), is an adequate scenario for studying the technological innovation in the lodging activity. Most of the hotels in the Balearic

\footnotetext{
${ }^{1}$ For the Spanish case, the correlation coefficient of R\&D and Innovations intensity of the 17 regions with the percentage of the economy production of industrial goods is 0.71 , and statistically significant.
}

Islands are specialized in providing a standardized tourist service called "sun and sea".

The paper draws on the innovation features in tourism activities. The study presents empirical evidence of hotel activity for the innovation process for a representative set of hotels to understand the characteristics and determinants of the managers innovation decisions. Specifically we consider the relationship between innovation propensity and hotels category, governance settings, size, and a group of variables capturing market conditions. The results are that the higher category is linked with major innovation intensity. Chain of hotels seem to provide a better environment for innovation decisions as the professional management contracts also seem to do. As known from previous services research, tourism activities are supplier-driven activities in terms of innovations decisions.

The paper is organized as follows: Section 2 introduces the theoretical framework; Section 3 analyzes the influencing elements of accommodation activity; Section 4 includes methodological aspects of the research. Finally, there are sections on results, and discussion, with some concluding remarks.

\section{Theoretical framework}

Technological innovation is usually defined as the conversion of technological knowledge into new products, new services or new processes introduced into the market, as well as the significant technological changes in products, services and processes. In order to achieve innovation, scientific knowledge is not enough: the outcome of such knowledge must be applied in a tradable way (Landau, 1991). Technological innovation is also depicted as an improvement in a product or service performance in terms of quality, cost, speed or number of characteristics (Cohen \& Levinthal, 1990). These approaches, typical to the manufacturing industry, refer to a product as the company output.

The technological innovation within the tourist accommodation activity has to capture the particular and differential features of the sector, characterized by the nature of the service. According to Gallouj and Winstein (1997) there are some aspects that characterize service and have a great influence on the definition of technological innovation. Those can be relevant to the hotel activity.

- First, there is a close interaction between production and consumption (coterminality) that makes difficult the typical product and process manufacturing distinction. The coterminality implies that the innovation activities will focus on service individualization, adapting the service provided to the customer requirements. Moreover, the coterminality leads to a 
higher degree of service heterogeneity the exchange object differs from one case to another. Only institutional changes, effectively implemented as a business strategy, must be regarded as technological innovations, and not those spontaneously generated and derived from human interaction. This characteristic fits on the hotel set of services provided to their customers.

- The second is the intangibility and growing information contents in the provision of services. The information and communication technologies play a critical role in the innovation activities of tourist accommodation businesses: to reach the potential customers with information that helps to get a deeper understanding of the service purchased; to reach the largest share of the demand; to obtain and process the information for a better business performance.

- The role of human resources as a key competitive factor. The importance of the human factor in service activities is associated with the capability to establish the quality and features of the service finally provided. Training and education activities are explicitly considered as one way to improve and upgrade the technological capabilities of service companies.

- Changes in the organization architecture can be linked to the introduction of new technologies, and should be included as technological innovation activities. These organizational issues are relevant in the accommodation industry to fulfil the services requirements

The Community Innovation Survey $\mathrm{II}^{2}$ definition of technological innovation, based on the Oslo Manual (OECD, 1997), applies to the accommodation industry in the sense that innovations refer to implemented new or significantly improved services or service production or delivery methods. New or improved services are regarded as innovation when their characteristics and ways of use are either completely new or significantly improved qualitatively or in terms of performance and technologies used.

It is generally accepted that new or significantly improved production methods require changes in the equipment. Also, the technologies used in the implementation of new or significantly improved services are frequently associated with machinery, equipment and software upgrading. These ideas are a starting point of the Barras' reverse product cycle framework for the information technologies based services innovation. Barras (1986) reverses the product cycle theory for the services industries in the sense that the technological

\footnotetext{
${ }^{2}$ The Community Innovation Survey II was launched in 1997 for the service industry and is able to differentiate services from manufactur ing schemes.
}

innovation is first introduced to increase the efficiency of existing services; for a second step, the technological innovation increases the quality of services; finally the innovation drives new services or wholly transformed traditional ones.

The influential Barras' perspective focuses on the information technologies related innovation in services where information intensity is important. For those services where interactivity seems to be more relevant, like accommodation in tourism, the pattern differs. Effectively, Sundbo and Gallouj (2000) assert that Barras' reverse product cycle is closest to a theory of diffusion of technological innovations in the services activity. They draw a set of typical innovations patterns where accommodation activities would fit in between the called "artisanal pattern" and "network pattern" with a supplier-driven process.

Technological innovation can be generated internally and also outsourced and there is no empirical evidence on the accommodation activity innovation pattern. In this sense, the hypothesis would be in line with some empirical findings on technological innovation in the service industry which show that, with the exception of knowledge intensive based services like data processing or telecommunications sectors, most companies innovate through purchase of equipment, components and materials from their suppliers (Barras, 1986; Sirilli \& Evangelista, 1998).

\section{Influencing elements of innovation in accommodation activity}

There are three main characteristics of the hotel industry that make different from other service activities. First, there is the regular category classification of hotels. The "stars" categorization that goes from 1 to 5 determines the type, number and quality of services provided. Second, it is relatively usual to have firms specialized managing hotels; and many combinations arise. There are hotels where owners manage themselves the activity, owners that rent the hotels, or professional executives running hotels through a management contract; another combination is the hotel management under a franchise contract. Third, there is remarkable characteristic of the hotel industry: the organization through chains of hotels, having a central office which has, depending on the company, different attributions and several degrees of vertical integration.

This exploratory research suggests that these hotel industry specific aspects can help to understand the innovation propensity of the accommodation services activity. Also, the untested Sundbo and Gallouj (2000) supplier-driven hypothesis from the patterns they define is explored. In addition, there are some remarks of the innovation supporting process that focus more on the 
literature on organizational innovations on services, (Van der Aa \& Elfring, 2002) where the organizational aspects of the implementation of innovations become relevant. There are also, some variables like firm size that usually have been introduced as explanatory in the propensity of manufacturing firms to innovate and should also be considered in the services innovation. Finally, we consider the market and competition conditions as a potential incentive to innovate and care for the firm competitiveness.

\subsection{Hotel-specific characteristics: category, governance and chain structure}

The ownership structure and the degree of dependence on other organizational structures influence the framework of management innovation decisions. In this sense, Davies and Downward (1996) and Jones (1999) show the importance of chains and groups of hotels. Some hotels are independently managed; others belong to a hotel chain or to a more diversified company conglomerate. Ownership and management do not necessarily happen together: (i) companies specialized managing hotels rent the assets or (ii) hotel owners contract the management abilities through management or franchise contracts. As Sirilli and Evangelista's (1998) suggest, different organizational structures of the production units may affect the innovative behavior.

The hotel category classification indicates the level and complexity of services provided. Their influence over the innovation propensity is simultaneously an endogenous and exogenous outcome. It is endogenous in the sense that higher categories include more services, equipments complexities and organizational aspects to be innovated. On the other side, a category cross comparison is able to explain some of the innovation patterns.

\subsection{Supplier driven}

Some services (e.g., information and communications technologies) are intensive in the use of new knowledge to innovate. Pavitt (1984), and more recently Hjalager (2002), characterize the hotel industry as a supplierdominated sector that innovates throughout the incorporation of technological elements developed by its suppliers. Similarly, Sundbo (1997) in a study of financial services, tourism and management consultancy, concludes that these service innovations are not science based.

The way which technology is introduced reveals the innovation pattern. Hotels can develop new technology internally or use elements developed by others. The hotel's collaboration in the development and implementation of these technological assets reveals the innovation patterns.

\subsection{Innovation supporting process}

Some functional areas, departments and company services can be easily identified as spaces where technological innovation takes place. Identifying technological incorporation implies the assignment of innovations to the different business areas where technology is likely to be transformed into competitive advantage higher productive efficiency (costs reduction) or differentiation. Furthermore, as long as technological innovation leads to more rapid reaction to the changing environment conditions and is integrated in an overall company strategy, it can be considered a way to improve competitiveness. This can be measured through the changes in the services provided by hotels along time.

The intensity of the changes introduced and the impact of the technological innovation have been usually defined as incremental or radical according to Deward and Dutton (1986) and Ettlie, Bridges and O'keefe (1984). A radical innovation is the application of a solution for a problem that had so far not been solved, or had been solved in a significantly inefficient manner (such inefficiency may not be evident until the new solution is found). The management of the solution frequently carries high costs, derived from the purchase or the necessary adjustments in the company's internal organization. However, the potential positive impact on performance is usually high too. Incremental innovation is defined as a progressive refinement of previously used solutions that allow an efficiency increase. This implies lower costs, and the benefits accrued are accordingly lower, regardless the importance of the continuous incremental innovation within the overall development. A typical example of the distinction between both innovation styles is the use of internet technologies: when they were first introduced in company management, a radical innovation occurred, whereas further extensions of their use resulted in incremental innovation.

Nevertheless, the innovation process does not conclude with the incorporation of new or modified technological elements. A great deal of effort must be put into their implementation (operation start up, adjustments, etc.) and their efficient use, enabling the organization to develop the skills required to successfully implement the innovations (Olsen \& Connolly, 1999; Sirilli \& Evangelista, 1998). In order to achieve an optimal operation of the new or significantly improved services, some changes in the employee's organization and training must be done (Cohen \& Levin, 1989; Griliches, 1990). This study looks also on the training and human resources investment, as a factor to understand the propensity to innovate and the quality level offered by a service company. ${ }^{3}$ Pine (1992) shows

\footnotetext{
${ }^{3}$ Moutinho et al. (1995); Saleh and Ryan (1992) provide support to this hypothesis.
} 
evidence that the transfer of technology in lodging activities depends on the staff's implication.

\subsection{Firm (hotel) size}

The size dependence of intensity of innovation among innovative firms is idiosyncratic. Some studies suggest a U-shaped curve, like Brouwer and Kleinknecht (1997) when analyzing the size distribution of innovative activity, comparing services and manufacturing.

The production unit size is relevant since the economies of scale may explain some strategic decisions made by companies. The influence of size on a company's innovative behavior has been outlined in some studies like Cohen and Levin (1989). The influence can empirically be positive (impact of scale economies on innovation activities) or negative (the effect of flexibility on the introduction of changes). The size of the hotel is able to determine the success and profitability of the implemented innovations.

An important issue in the hotel industry related to the size effect is the combined requirement of both fixed assets as equipments and human resources in the service delivery process. Therefore, the industry must face a very high fixed costs structure. This fact, together with the typical seasonal demand of many coastal resorts, makes it more profitable for many companies to shut down during the low and/or medium seasons than staying operative. Moreover, the acceptable occupancy break-even level is quite high, which constrains price policy (Kotas, 1982; Tisdell, 2000). This phenomenon increases the tour operators' negotiation power. The technological innovation may mitigate these difficulties by offering tourist products off season (Carey \& Gountas, 1997) short breaks, business trips, etc. or increasing the use of the installed capacity.

\subsection{Market factors and competition}

The hotel activity targets to specific market segments related to quality and categories levels, seasonality and possibilities of product differentiation. The market segment can be approached, according to Davies and Downward (1996), through the type of board sold, the channels used in commercializing the service and the degree of customer loyalty. Innovation propensity can be explored according to these features. The channels used to commercialize the service can also be innovated through the new possibilities offered by the information and communication technologies (e.g., booking via the Internet) or else improved use of these new technologies (Sangster, 2001).

The hotels' differentiation is the strategic behavior related to its closest competitors, companies with similar services in the same area. Using technological innovations, as a way to differentiate services, can provide tourist accommodation services in addition or higher quality than those of their competitors. This differentiation, according to Chung and Kalnins (2001) is considered a major competitive variable, achievable through innovation.

The information sources publicly available as databases on $R \& D$, patents registries and similar are useful to quantify the innovation activities in the manufacturing industry but helpless in our case. To identify innovation activities within the lodging industry the information arises from direct sources, from the same facilities providing tourists accommodation services. The unit of analysis is the hotel instead of the firm. The hotel is the place where the service is provided, where the managers have the incentives to innovate, where the innovations can be measured without the aggregation of hotels at firm level.

\section{Data and methodology}

The data base used for this study has been provided by the Conselleria de Turisme (the Regional Tourism Authority; Conselleria d'Economia). It consists in all the hotels operating in the Balearic Islands listed in the official census, 1.586 units since tourist apartments and those labeled as "Others" are excluded. Tourist apartments are excluded due to differences in type of services they provide and regulatory schemes. The category labeled "Others" (e.g., rural tourism) represents a mere $0.5 \%$ of the total population and is heterogeneous in its operations and the package of services offered. Therefore, the variety of accommodation possibilities includes guesthouses, hostels, apart-hotels and hotels.

In obtaining a representative sample of the population, a profile has been outlined according to three distinctive characteristics: geographical location (three islands in the Balearic archipelago), category and hotel size. The population was first divided into homogenous groups (layers) according to their distinctive characteristics to undertake, then, a simple random sampling process in every layer. Therefore, the 1.586 hotel establishments and their beds were grouped in 12 layers, resulting in the combination between the four categories (1, 2, 3 and 45 star) with the three geographical locations: Majorca, Minorca and Ibiza/Formentera.

Table 1 depicts the sample structure and shows the relevance according to the population composition. The number of hotels and their size have a similar proportion as that in the population which indicates the sample is a good representation of the Balearic hotel industry.

To obtain the information from the hotels, a questionnaire was designed and answered by hotel's directors, or management representative they indicated, through a direct interview in the hotel's location. In order to filter problems with some questions, a pilot 
Table 1

Sample and population distribution ${ }^{\mathrm{a}}$

Number and percentage of sample hotels

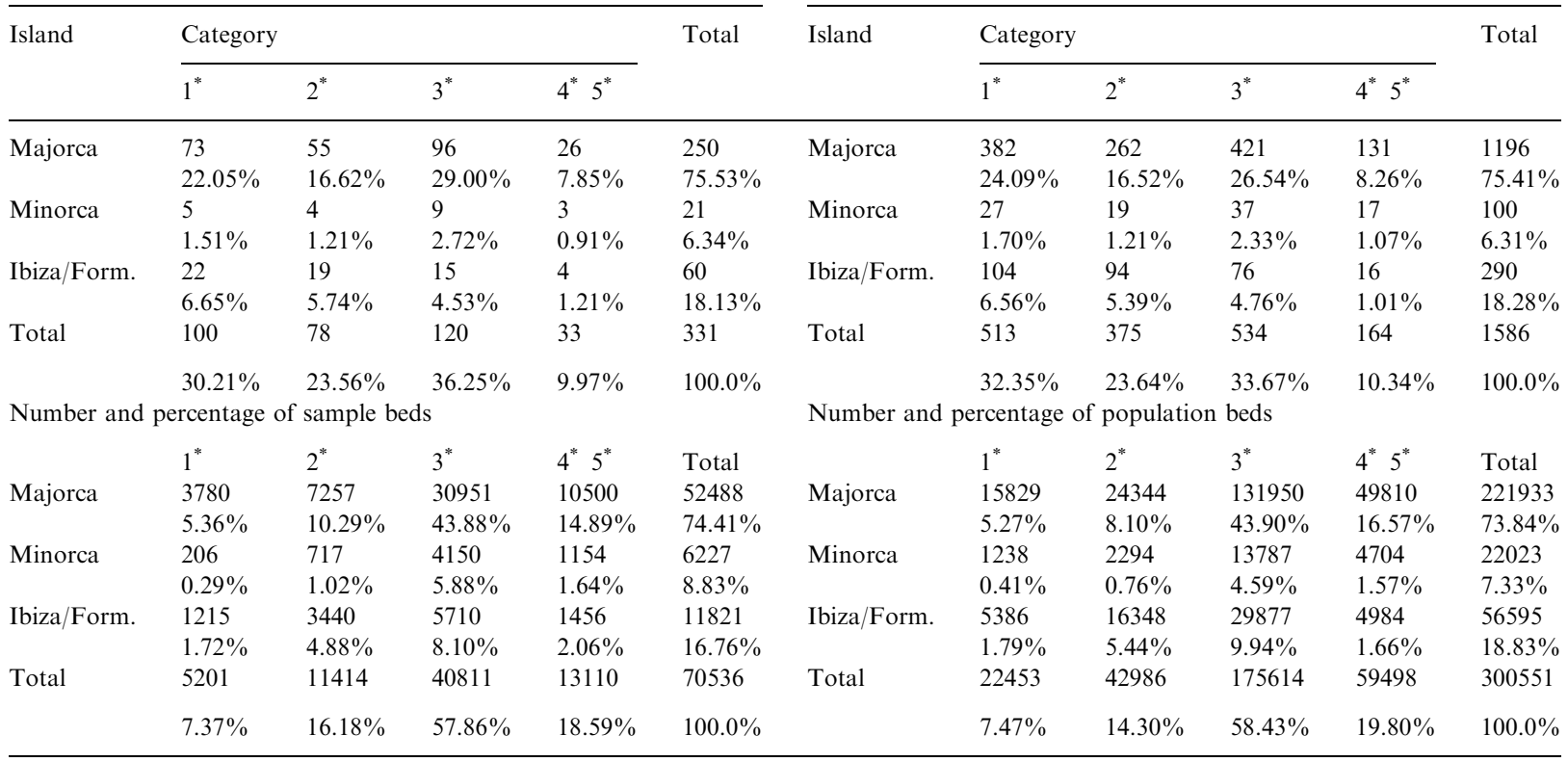

${ }^{a}$ Number and percentage of the hotel establishments and capacities in the population and in the sample ranked by categories and by islands. questionnaire was sent to the managers conforming a total of nine hotels divided into the following categories: 1 to the 1 star in Menorca, 2 to the two stars (one in Mallorca and one in Ibiza/Formentera), 3 to the three stars (one in each isle group), 2 to the four stars (one in Menorca and one in Ibiza/Formentera) and, finally, one to the five stars in Mallorca. From the information provided by these pilot responses, the questionnaire design consists of two parts. The first one and more important, is concerned to the firm's characteristics and technological activity with compulsory qualitative responses. The second part includes a set of optional questions about the labor force as full or part time contracts, education level; and some operational aspects as average level of occupation of the hotel.

The final questionnaire was answered by 331 managers of the sample using peer responses of interviewers which were trained to carry out the work.

The main analyzed variables have been constructed as follows. Category measures the number of stars that Tourist Administration catalogues a hotel according to legal requirements and technical specifications. The legal five categories have been aggregated in four jointing those establishments with 4 and 5 stars. Establishments in the top category ( 5 star) represent no more than $1 \%$ of the overall capacity while their technical differences with respect to 4 star establishments are hardly scarce.

Governance indicates who manages the hotel operations: the owner of the physical assets or another one through a management or leasing contract. Those establishments directly run by the owners i.e., where property and management fall in the same hands are labeled "Owners" as a management type. Those establishments where a professional firm runs the activity with a management contract with the hotel owners are labeled "Management" as a management type. Finally, the establishments monitored by who hires the physical assets to the property to provide accommodation services are labeled "Leasing" as a management type. Chain structure refers the way in which the establishment operates in the market: independently or belonging to a hotel chain or to a business conglomerate more diversified (together with companies not operating in the lodging sector). First case is classified as independent or not-chain while the others are as chain.

Supplier-driven pattern is approached by the way which technology is introduced purchase, lease, internal development, subcontract or use of elements centrally owned by the parent company and the hotel's collaboration in the development of these technological assets captures the hotel technological equipment activity.

In Innovation Activity measurement, Innovators are those establishments that in the two previous years have introduced some changes in one or more key business areas where technology is likely to be transformed into competitive advantage higher productive efficiency or differentiation (these areas are listed in Table 4). 
Innovation in the production process at this technical level account for the introduction of internally developed innovations or innovations purchased from suppliers. The managers interviewed were asked to rate every activity area likely to incorporate innovation, on the basis of the examples shown by the surveyors, in one of the four following categories: (i) no change, (ii) radical innovation, (iii) incremental innovation or (iv) the activity concerned is being outsourced or provided by company's central services. In business areas or activities outsourced or provided by the central services of a parent company, the decision to innovate will not only depend on the hotel. The answers of categories (i) and (iv) are ranked as non-innovators. Areas first time innovated are rated as radical innovation while improved, widening or renewal areas previously innovated are rated as incremental innovation.

The Human capital skills adjustment approximates the effort put into successful innovation implementation. The changes experienced in the human capital skills and capabilities are captured with the changes in training and human resources investment. That is, the innovators were asked about the adaptation of skills and capabilities of their human capital through internal training, external training, contracting new workers, outsourcing or using the central services. Additionally, the human capital is approximated in two ways. One way refers to fixed or temporary contracts. The second one refers to the education level that has been classified into three levels: primary education, secondary or professional education and university education. Given that responses about human capital skills were optional, these only covered a $71.9 \%$ of hotels for fixed or temporary contracts, and around $61 \%$ for the education level.

The hotel Size accounts for the number of beds installed in the hotel. Three reasons justify the use of the number of beds in measuring the size of a hospitality establishment. One is the data availability compared to alternative measures as number of workers. The labor contracts are commonly registered through intermediate companies whose activity is not necessarily related to the subject of this study. The second reason is that for the study objectives, the size of the operating unit will allow bypassing higher-order units, such as legal entities or firm level. Finally, it is a common practice in the literature on hotel activities to use the number of beds or the equivalent number of rooms as an indicator of the hotel size (Baum \& Mezias, 1992; Chung \& Kalnins, 2001; Fernández \& Marín, 1998) and will allow making future homogenous comparisons.

The variables that help to define the Market segment targeted by the establishment are the type of board sold, the ways to contract the accommodation service and the degree of customer loyalty. The type of board sold to the average guest fit into three categories: less than half board (accommodation only or bed and breakfast), half board (accommodation, breakfast and one meal a day) and more than half board (full board or all-inclusive). The channels used to commercialize the service may be one or more from tour operator, travel agency, reservation center and direct contract. Additionally, the number of tour operators every establishment operates with is a proxy of the negotiation power and of the customer dispersion, with potential influence on the perceived need to innovate. Establishments enjoying the stay of repetitive average guests have calculated the customer loyalty.

The total months a year one establishment operates approximates the intensity in the use of the assets Seasonality since for some hotels is more profitable to shut down during the low season than remains open. Joint effects of the seasonal demand and the high fixed costs structure of the hotels (Kotas, 1982; Tisdell, 2000) make it more profitable for some hotels to shut down during the low and/or med seasons than to stay open, determining the intensity in the use of the hotel

The strategic behavior related to its closest competitors in the sense of the strategy pursued by every hotel may be differentiated in terms of service provided or service provision process and delivery. Then, for Differentiation analysis the hotels sampled have been classified attending to the different innovation impacts approaching their strategies. Establishments with differentiation strategy are those with objectives on customer loyalty increment or warranty contracts, services differentiation and quality improvements. Establishments with costs leadership strategy are those identified with costs reduction, labor productivity or profitability improvement.

Performance is measured following the average occupancy rate due to the hotel managers reluctant to provide details about their hotel's financial performance while average occupancy rate is widely used among hotels (Alvarez Gil, Burgos Jiménez, \& Céspedes Lorente, 2001). Nevertheless, responses about average occupancy rate were optional and available data are 271 observations, the response level being around $81.87 \%$.

\section{Results}

Split the sample into categories, as Fig. 1 shows, the average size is increasing with category. There are differences in the average size among categories statistically significant at $5 \%$ level, except for the case of 45 star hotels with respect to 3 star hotels. This is remarkable because medium and high-quality hotels are predominant in the hotel activity. The dispersion of the size (standard deviation) is especially large for 2 and 3 star hotels.

From Table 2, the governance and chain structure distribution can be linked with category and size. The 
ownership of hotel not affiliated to a parent company is the most frequent in the sample $(66.47 \%)$. The decreasing proportion of hotels operating independently in the market by category and size is statistically significant and similar to the characteristics portrayed by Jones (1999). The increasing average size by categories (Fig. 1) jointly with the decreasing proportion of independently operated hotels by category and size (Table 2) show that independently operated hotels are, in average, smaller and of inferior category. One interesting data is that hotels managed by their owners are the dominant governance structure, remarkably more frequent in 1 star hotel. As category increases, the proportion of establishments directly runs by the owners and the proportion of leased property decrease, while the proportion of establishments runs through management contracts increases. By size intervals, the proportion of establishments where ownership and management fall in the same hands decreases for larger establishments, while the use of management contracts expands. On the

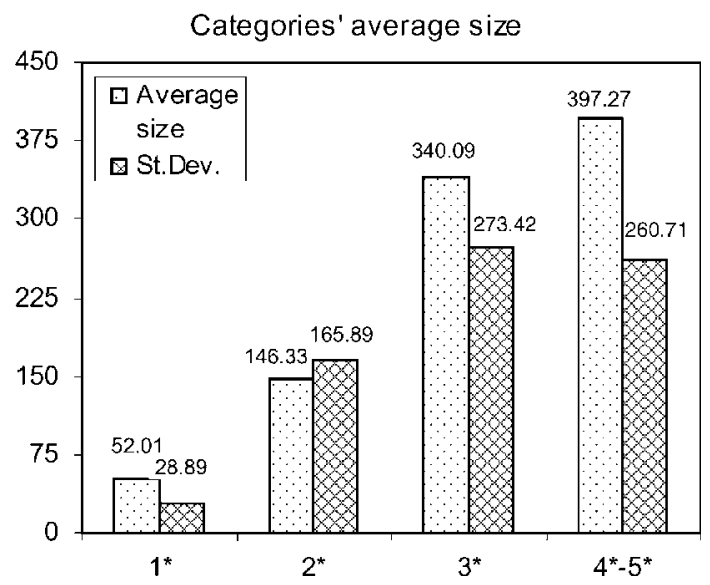

Fig. 1. contrary, the proportion of leased properties is higher in smaller establishments.

\subsection{Supplier-driven pattern}

Innovation in the hospitality business implies the use of technologies usually embodied in new machinery, equipment or software (technological assets). Then, it is important to ascertain to what extent the innovations undertaken have required the development, purchase or use of new machinery or technological equipment, termed here "technological base of the introduced innovations". Of the total 285 defined as "innovators", $272(95.44 \%)$ have founded such innovation on a technological base. Additionally, Table 3 displays the way in which technology is introduced and the establishments' collaboration in the development of these technological assets the hotels' technological activities.

Almost $80 \%$ of the activities have consisted on the purchase and installation, while internal R\&D activities is not significant and only $6 \%$ is committed in joint efforts basically suppliers collaboration. Additionally, only $25 \%$ of interviewed companies make use of external information sources to innovate. This is indicative of a very low level of cooperation among entities.

\subsection{Innovation supporting process}

Table 4 presents the technological assets incorporations in those functional areas, departments and company services where technological innovations take place.

Lower rates of innovation are for quality and environmental quality management, although the changes, when introduced, have been mostly radical. A more innovative behavior is found in hardware and computers facilities and kitchen and restaurant equipment. ICT (Information and Communication

Table 2

Governance and chain structure by category and size $\mathrm{e}^{\mathrm{a}}$

\begin{tabular}{|c|c|c|c|c|c|c|}
\hline \multicolumn{2}{|c|}{ Governance and chain } & \multirow[t]{2}{*}{ Not Chain } & \multicolumn{3}{|c|}{ Governance } & \multirow[t]{2}{*}{ Total } \\
\hline & & & Owners & Management & Leasing & \\
\hline & $2^{*}$ & 82.05 & 74.36 & 17.95 & 769 & 100 \\
\hline & $3 *$ & 44.17 & 64.17 & 31.67 & 417 & 100 \\
\hline & $4^{*} 5^{*}$ & 24.24 & 66.67 & 30.30 & 303 & 100 \\
\hline & $122 \quad 299$ & 58.54 & 70.73 & 21.95 & 7.31 & 100 \\
\hline & $\geqslant 300$ & 27.71 & 65.06 & 32.53 & 2.40 & 100 \\
\hline Total & 66.47 & 71.90 & 21.45 & 6.65 & 100 & \\
\hline
\end{tabular}

\footnotetext{
${ }^{a}$ Numbers refer to the percentage of establishments in the sample.
} 
Table 3

Hotel's technological equipment activity

\begin{tabular}{|c|c|c|c|c|c|}
\hline Technological equipment activity & Abs. freq. & $\%$ on total activities & $\left(^{*}\right) \ldots$ with & Abs. freq. & $\%$ \\
\hline Modified or adapted & 44 & 14.01 & Consultants & 3 & 15.79 \\
\hline Developed jointly with...(**) & 19 & 6.05 & Subtotal & 19 & 100.00 \\
\hline Total & 314 & 100.00 & & & \\
\hline
\end{tabular}

Table 4

Technological innovation degree by areas ${ }^{\mathrm{a}, \mathrm{b}}$

\begin{tabular}{llccc}
\hline Areas of technological innovation & No change & Radical innovation & Incremental innovation & Outsource/central \\
\hline Quality management & 73.72 & 14.50 & 8.76 & 3.02 \\
Environmental quality management & 80.66 & 10.27 & 6.65 & 2.42 \\
Hardware and computer systems & 32.33 & 11.78 & 51.65 & 4.23 \\
ICT in external management & 56.50 & 25.98 & 13.90 & 3.63 \\
ICT in internal management & 67.67 & 13.60 & 5.31 & 2.42 \\
Kitchen equipment & 38.07 & 2.11 & 60.42 & 0.60 \\
Restaurant equipment & 36.86 & 2.42 & 74.32 & 0.30 \\
Rooms facilities & 23.26 & 2.11 & 25.98 & 0.30 \\
Maintenance and saving in supplies & 54.68 & 18.43 & 33.84 & 0.91 \\
Security systems & 48.64 & 14.80 & 24.77 & 2.72 \\
Laundry and cleaning & 50.76 & 3.32 & & 21.15 \\
\hline
\end{tabular}

${ }^{\mathrm{a}}$ Figures are expressed in percentage of sample hotels.

${ }^{\mathrm{b}}$ Technological degree is defined as:

(a) No change: establishment does not carry out any innovation activity.

(b) Radical innovation: establishment introduces innovation at first time.

(c) Incremental innovation: establishment introduces innovation to improve a previous innovation.

(d) Outsource/central: establishment outsources or use the central services of a parent company.

Technologies) to manage external information has experienced twice as much radical innovation as ICT focused on internal information management in spite of the high percentage that has introduced no changes. The most incremental innovation is found in rooms facilities. The most innovative establishments in all areas are 3 and 45 star hotels, while the innovative behavior in 1 and 2 star hotels takes place in areas such as computer facilities and hardware, especially with radical innovations.

Out of the 331 surveyed hotels, $285(86.10 \%)$ have declared innovators and $46(13.90 \%)$ do not. Innovation is, therefore, a highly common phenomenon given our definition, in the sense that at least one area has been incrementally innovated. In terms of statistical significance the percentage of 2 star innovative hotels $(87.18 \%)$ is higher than for 1 star hotels $(68 \%)$; the proportion of 3 star innovative hotels (97.50) is higher than for 2 star hotels, and there are not significant differences between the innovation percentages corresponding to 3 and 45 star hotels $(96.97 \%)$. These conclusions validate the results of the analysis by categories of innovation in the different areas. Addi- tionally, the innovators average size, 230.52 beds, is statistically bigger than the non-innovators average size, 105.15 beds, at a $5 \%$ significance level.

The innovative behavior (percentage of innovative establishments versus non-innovative ones) by chain and governance structure (Table 5) presents differences as compared to the general behavior. Only four establishments belong to a conglomerate and thus, the results are not very representative of this ownership type.

The percentage of innovative establishments is somewhat lower in hotels operating independently and in hotels managed by the owners. In hotel chains, establishments managed by contract and in hotels run in leased properties, this percentage is higher.

In the human capital skills updating, there are 55.44\% of the innovators that have adapted their human capital. The average size of the hotels that have undergone these adjustments, 301 beds, is significantly larger than the average size of the hotels where no adaptation has been made, 141 beds. A $44.26 \%$ of the hotels sampled that were not integrated in a hotel chain underwent adjustments, whereas for hotels belonging to chains, this figure increases up to $75.49 \%$. As regards the way that human 
capital skills and capabilities have been updated, Table 6 shows a greater incidence of the internal training.

Referred to the importance of fixed contracts in the hotel industry, we observe in Table 7 , panel A, that contrary to expect small innovating firms use more those contracts than large and innovating firms. When we split the sample in the percentage of skill workers employed in the hotels, panel B, results report interesting differences between innovators and non-innovators. In general, the behavior is expected innovating firms hire more skill workers but with an exception the first category where the percentage of high-skill workers is bigger for non-innovators due basically. It indicates some relevant finding that non-innovating hotels with a low category hire qualified employees in order to capture some position in the market.

\subsection{Market factors and competition}

The currently board regime most contracted by the average guest is the half board. The board regime contracted by the average guest is related to innovative behavior: more than half of non-innovating firms
$(67.39 \%)$ the regime contracted is less than half board while the customers of a $53.5 \%$ of innovators use a full board or all-inclusive.

From the analyzed channels used to commercialize the service (tour operator, travel agency, reservation center and direct contract) booking with a tour operator is the most common solution. Reservation centers are, in quantitative terms, the least preferred option. By categories, 1 and 2 star hotel guests book directly or via tour operator, whereas tour operators are the dominant to contract 3 and 45 star hotels. Especially remarkable are the significant number of hotels that operate with only one tour operator $(29 \%)$ and the fact that the average number of tour operators statistically increases with category. The channel used to commercialized the service is also related to innovative behavior since the innovators' percentage increases with the tour operators' importance in booking: $71.21 \%$ do not use tour operators, $84.93 \%$ make use of tour operators among others channels and $91.67 \%$ only commercialize with tour operators.

The average customer loyalty found is that $73.72 \%$ of the establishments declared enjoying the stay of

Table 5

Innovation activity by chain and governace structure ${ }^{\mathrm{a}}$

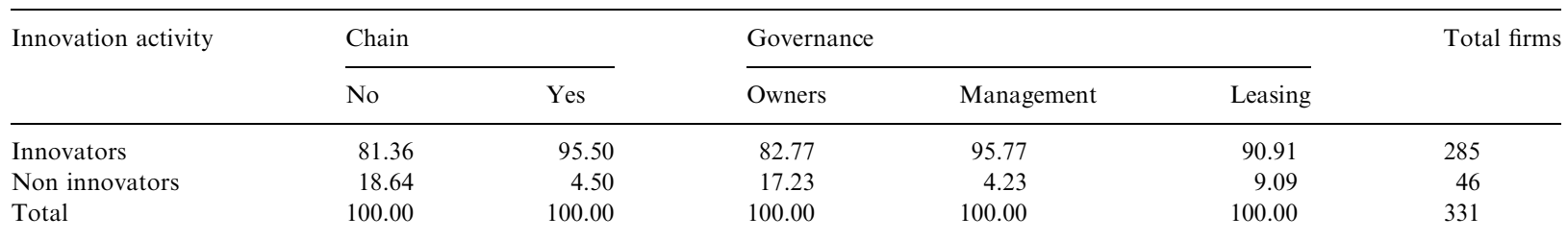

${ }^{\mathrm{a}}$ Percentage of establishments.

Table 6

Forms of human capital skills updating ${ }^{\mathrm{a}}$

Hotel specific characteristics and size Updating skills Updating human capital skills form

Internal training External training New workers Outsourcing Central/parent services

\begin{tabular}{|c|c|c|c|c|c|c|c|}
\hline \multirow[t]{4}{*}{ Category } & $1^{*}$ & 25.00 & 10.29 & 14.71 & 2.94 & 0.00 & 0.00 \\
\hline & $2^{*}$ & 51.47 & 35.29 & 16.18 & 2.94 & 4.48 & 4.48 \\
\hline & $3^{*}$ & 66.67 & 47.01 & 31.62 & 16.38 & 11.11 & 3.42 \\
\hline & $4^{*} 5^{*}$ & 87.50 & 78.13 & 28.13 & 18.75 & 21.88 & 9.38 \\
\hline & $\begin{array}{ll}50 & 121\end{array}$ & 34.72 & 22.22 & 18.06 & 2.78 & 2.82 & 0.00 \\
\hline & 122299 & 73.08 & 47.44 & 34.62 & 16.67 & 7.69 & 2.56 \\
\hline & No & 43.58 & 25.14 & 20.11 & 7.26 & 3.93 & 1.12 \\
\hline \multirow[t]{3}{*}{ Governance } & Owners & 52.79 & 37.56 & 23.86 & 4.59 & 6.63 & 2.54 \\
\hline & Management & 61.76 & 44.12 & 20.59 & 23.53 & 14.71 & 5.97 \\
\hline & Leasing & 60.00 & 35.00 & 30.00 & 20.00 & 0.00 & 5.00 \\
\hline Total & 55.44 & 38.95 & 23.51 & 10.21 & 8.10 & 3.52 & 3.52 \\
\hline
\end{tabular}

${ }^{\text {a }}$ Percentage of establishments. 
Table 7

Human capital by innovation activity and category

(A) Fixed versus temporary employees ${ }^{\mathrm{a}}$

\begin{tabular}{|c|c|c|c|c|c|c|}
\hline Innovation activity & \multicolumn{4}{|c|}{ Category } & & \\
\hline Yes & 61.09 & 67.22 & 57.99 & 52.91 & & \\
\hline Total & 59.74 & 69.88 & 57.81 & 52.79 & & \\
\hline \multicolumn{7}{|l|}{ (B) Employees education ${ }^{\mathrm{b}}$} \\
\hline Innovation activity & & $1^{*}$ & $2^{*}$ & $3^{*}$ & $4^{*} 5^{*}$ & Total \\
\hline \multirow[t]{3}{*}{ No } & $\mathrm{U}$ & 11.95 & 2.70 & 0.00 & 10.00 & 8.57 \\
\hline & $\mathrm{S}$ & 11.47 & 41.40 & 0.00 & 40.00 & 23.18 \\
\hline & $\mathrm{P}$ & 76.58 & 55.90 & 0.00 & 50.00 & 68.25 \\
\hline Yes & $\mathrm{U}$ & 5.10 & 6.63 & 7.16 & 8.47 & 6.71 \\
\hline \multirow{2}{*}{ Total } & S & 28.93 & 33.58 & 32.84 & 42.50 & 32.91 \\
\hline & $\mathrm{P}$ & 63.90 & 60.53 & 60.00 & 48.95 & 60.12 \\
\hline
\end{tabular}

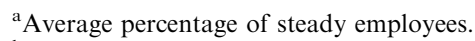

${ }^{\mathrm{b}}$ Average percentage of employees with university (U), secondary or professional (S) and primary education (P).

repetitive guests. Nevertheless, customer loyalty is not empirically associated with innovation: innovators customer loyalty hotels enjoying the stay of repetitive guests equals the non-innovators.

As regards seasonality, the Balearic Islands are characterized, as a destination, by a high specialization in the "sun and sand", tourist segment, typical of the summer season. In the year $2000,58.3 \%$ of all tourists arrived in the summer season (June through September), $29.6 \%$ in the mid season (April, May and October) and $12.1 \%$ in the low season (November through March) (La Despesa Turística, 2000). Consequently, half the establishments are closed during the low season, while only a fifth part of the total hotels sampled are open all year long. The intensity in the use of the hotel is related to innovation as the innovators percentage increase by this intensity: $60 \%$ opens during the high season, a $84.90 \%$ open during high and medium season and a $88.02 \%$ open all year.

Differentiation the strategic behavior related to its closest competitors in terms of service provided or service provision process and delivery reveals a highly homogeneous average supply: $56.50 \%$ of undifferentiated establishments, $12.08 \%$ of costs leadership strategy and $38.37 \%$ of service differentiation strategy. By categories, 1 and 2 star are the least differentiated categories and half the establishments in the 3 and 45 star categories present no differentiation. Table 8 evidences the relationship between differentiation strategy and innovative behavior:

Finally, we cross-tabulate innovation and a performance proxy in order to capture some differences in the feasibility of innovation activity and its capacity to generate rents to firms. By assuming that a good performance corresponds to higher levels of occupancy, results report interesting figures. The occupancy rate is largo for innovators $(81 \%)$ than for non-innovators $(75 \%)$.

\section{Discussion}

The increasing average size by categories (Fig. 1) can be associated with the greater organization complexities and management difficulties. Categories are associated with more complex technical requirements required by law, and size also means more organizations difficulties. In fact, Chung and Kalnins (2001) find that large hotels are typically more luxurious than small ones and argue that the larger have more features because facility enhancements require economies of scale.

The decreasing proportion of hotels operating independently in the market by category and size (Table 2) may be explained on the basis of the management complexity and budget constraint. Belonging to a hotel chain or a business conglomerate allows to the 
Table 8

Differentiation strategy and innovation ${ }^{\mathrm{a}}$

\begin{tabular}{|c|c|c|c|c|}
\hline Innovation activity & \multicolumn{4}{|c|}{ Differentiation strategy } \\
\hline Yes & 13.68 & 41.75 & 52.98 & 108.42 \\
\hline Total & 12.08 & 38.37 & 56.50 & 106.95 \\
\hline
\end{tabular}

${ }^{\text {a }}$ Percentage of establishments.

${ }^{\mathrm{b}}$ Total exceeds 100 because some hotels declare their strategy in both terms.

companies to accumulate management know-how (Darr, Argote, \& Epple, 1995), information flows and the possibility to built intangible assets such as brand image and prestige (Ingram, 1996; Ingram \& Baum, 1997). Thus, belonging to a chain provides management know-how and intangible assets that can be more valuable for larger hotels, achieving economies of scale. The findings about governance decreasing proportion of hotels run by the building owners and the management contract increasing suggest that management specialization increases with organizational difficulties (category, and hotel's size). The low ratios of rented properties may be a consequence of the risk associated to renting contracts of assets managed to provide accommodation services (the possibility of contract breakage and the negotiation costs). This risk increases with size and with hotel category given the more complex and strict legal regulations to be met by upper categories. The reduced use of renting and management contracts in 45 star hotels may well be explained by this argument.

Data about the way in which technology is introduced and the hotel's collaboration in the development of this introduced technology bear witness that the hotel industry is a sector dominated by suppliers (Pavitt, 1984), a non-intensively knowledge-based services (Sundbo, 1997) that innovates introducing R\&D embodied technology rather than undertaking internal R\&D activities (Sirilli \& Evangelista, 1998). Also, it supports the idea of dependence on suppliers product innovation and the lack of inter-organizational links that would stimulate technological innovation (Goes \& Park, 1997; Pennings \& Harianto, 1992).

The technological assets incorporation by areas where innovations take place (Table 4) is discussed by areas. The lowest innovation rates for quality and environmental quality management may be due to the relatively recent development of the quality control methods (Font, 2002). It may also be explained by companies culture that does not favor the implementation of techniques with immediate costs but long-term benefits, seemingly unaware of the key importance of delivering a quality service to achieve sustainable competitiveness, especially in the actual international competition frame- work unfeasibility of cost leadership strategies (Go, Pine, \& Ricky, 1994; Olsen \& Connolly, 1999). Furthermore, a "prisoner's dilemma" may be arising: the environment is a primary productive and competitive resource for the whole tourist destination (Hassan, 2000) whose preservation implies individual costs. Still, in some cases, the environmental quality management improves the company's financial performance (Älvarez et al., 2001). The higher innovation rate in hardware and computers facilities and kitchen and restaurant equipment may be explained by the lack of direct intercourse with the guest in these three operational areas. That is, these areas can be automated with no loss of the service's personal component. Moreover, the providers of this kind of equipment and technology offer new and improved tools and machinery that enhance the production and management efficiency, key factors to the hotel business profitability (Sheldon, 1983). As regards ICT, the double radical innovation to manage external information than internal may be associated with the earlier computerization of the internal management and the later availability in the market of computer and virtual webs (Wei, Ruys, van Hoof, \& Combrink, 2001). Nevertheless, the high percentage that has introduced no changes reflects the technological lag with the use of information as a source of sustainable competitive advantage (Buhalis, 1998; Camisón, 2000). The high incremental innovation in rooms reflects the importance of tangible assets directly used by the guest in the service consumption (Saleh \& Ryan, 1992). The service perceived quality level captures these improvements.

The findings according to quality categories reveal 1 and 2 star hotels have a lag introducing ICT compared to the average 3 and 45 star hotel. Furthermore, attending to innovators rate, the known positive relationship between size and category (Fig. 1) means that the categories where innovation will be more profitable i.e., scale economies also observed in other industries (Cohen \& Levin, 1989) are 3 and 45 star hotels. These categories are most able to differentiate the product, and as such, they will be prompt to resort to innovation. The lowest rate of innovation in 1 and 2 star hotels can be interpreted as the result of a "follow up 
behavior" that allow these establishments to stay in the market.

The percentage of innovator hotels in the sense that at least one area had been innovated, $86.10 \%$, is comparable to the $75 \%$ of innovators services firms in Germany, while the lower innovation rate, between $25 \%$ and $33 \%$, found in other countries like Australia or the Netherlands are explained by its narrow innovation definition (Hipp, Tether, \& Miles, 2000).

The higher innovator percentage among hotel chains (Table 5) is consequent with the knowledge on the innovative process flowing easily among all the members of the chain (Darr, Argote, \& Epple, 1995). Moreover, Tisdell (2000) finds that large hotel chains based in more developed countries are continually involved in R\&D product development and training. Nevertheless, the dynamic innovative behavior of the establishments managed through a management contract and of those run in a lease property is somehow counterintuitive. The risk associated to the contract has a negative impact on innovation incentives. However, the higher degree of specialization of managing companies (with better know-how and productivity) may explain a positive influence on the innovation perception benefits. That is to say that the innovation incentives derived from specialization may outweigh the negative impact of the highest risk associated to this kind of contracts.

The human capital skills and capabilities updating (Table 6) confirm the importance of changes in training and human resources investment (Cohen \& Levin, 1989; Griliches, 1990; Pine, 1992) to successful innovation (Olsen \& Connolly, 1999; Sirilli \& Evangelista, 1998). The larger size of the hotels updating its human capital skills and capabilities may suggest that scale economies arise in this process. As regards the way that human capital skills and capabilities have been updated, the greater incidence of internal training could be as a consequence of the specificity of the required skills specially if technological elements incorporated has to be tailored to the characteristics of the hotel. The higher proportion of internal training in chains may be associated also to sharing fixed costs with a larger number of employees training. Indeed, chains are characterized by a better training capacity as they are in Tisdell (2000).

Market factors results like the positive relationship between the board regime most contracted by the average guest and the innovation activity seem to confirms its importance in the innovative behavior. The findings about the channels used to commercialize the service may be related with following facts: (i) Reservation centers are mainly used as a way to book flights (Beaver, 1992); (ii) Better off segments tend to avoid non-monetary costs and the risks associated with direct booking by the guest preferring to contract with a tour operator; (iii) the aspects most controlled by the tour operators e.g., characteristics of the accommodation company's establishments and facilities; internal operations and conditions of the accommodation like security and safety inside the establishment; accommodation, leisure and food and beverage services provided; the environmental management and information and communication activities (Medina-Múñoz, Medina-Múñoz, \& García-Falcón, 2003) may be improved through innovation; (iv) Customer loyalty depends only partly on the degree of satisfaction derived from the accommodation service, since other tourist services are also consumed during the stay (Otto \& Ritchie, 1996); (v) The need to undertake a cost benefit analysis on output innovation, offering tourist products usually consumed off season e.g., short breaks, business trips, health tourism and heritage and nature-based tourism (Carey \& Gountas, 1997) and to introduce process technical innovation that reduces the high fixed costs.

The higher differentiation strategy among upper categories may be related to a targeted guest that appreciates quality and may be willing to pay higher prices for an enhanced quality. Nevertheless, the emphasis on quality as key competitive strategic variable, a priority in the current market environment (Gray, Matear, \& Matheson, 2000) does not apply innovating quality control techniques (Table 4).

Results about performance seem to suggest that innovation activity may generate rents to firms. Anyway, this innovation capacity is underestimated since these results link innovation with performance for only the same period while the capacity to generate rents may be longer.

\section{Conclusion}

This paper presents a descriptive analysis of innovation change in the hotels supplying tourist accommodation services in the Balearic Islands. The concept of technological innovation has been defined drawing upon the most relevant differential features of the lodging sector, highlighting the differences derived from its condition of service provider. According to Community Innovation Survey II, based on the Oslo Manual (OECD, 1997), when assessing innovation, the incorporation of technologies integrated in productive assets, in components and in outsourced services must all be taken into account. Furthermore, the sector follows a suppliers-dominated pattern and, the assessment of innovation may not be limited to the valuation of R\&D activities.

A specific designed questionnaire targeted to the managers of a representative sample of the hotels in the Balearic Islands shows some aspects of the hotel industry organization. These issues refer to some facts as: (i) the increasing average size of the hotels with 
category together with a high variability. (ii) The predominant ownership and management types are independent ownership and management by the owners, although their incidence decreases with category and average size. (iii) The most frequent channel to commercialize the service is via tour operators who may have a potential influence on the perceived need to innovate. Finally, (iv) the specialization in the sun and sand product implies high seasonality that tends to cause a low intensity in the use of assets.

The mentioned characteristics of the hotel industry are able to determine the introduction of innovations. Some remarks from this relationship are that (i) the average size of the innovators is larger, with 3 and 45 star hotels being more innovative. (ii) The innovation rate overcomes average for hotels that belong to a chain, in hotels under management contract and for hotels managed in leased properties. (iii) Almost $50 \%$ of innovative companies adjust the human capital skills and abilities. Hotels belonging to a chain are much more inclined to introduce adjustments. Finally (iv), we present as the patterns of incorporation of technological assets and of technological equipment-related activities show the hotel industry is a supplier-dominated sector that innovates introducing R\&D incorporated technology rather than undertaking internal $\mathrm{R} \& \mathrm{D}$ activities.

These findings inform of the levels and characteristics of the innovation undertaken and about the variables it is related to. Some of these results are new and have been studied at descriptive and univariate level. However, with regard to its potential spread and significance, these results are a first stage, since they point out a number of causal relationships that need to be analyzed with multivariate techniques. This will be the next step.

\section{Acknowledgements}

Authors want to acknowledge the support from the Catedra Sol Melia. This research also benefits from the BEC2001-2552-C03-03, Spanish Science Ministry research project and the financing of the Regional Authority for Research, Technological Development and Innovation of the Govern de les Illes Balears.

\section{References}

Aguilo Perez, E., \& Juaneda Sampol, C. (2000). Tourist expenditure for mass tourism markets. Annals of Tourism Research, 27(3), 624637.

Alvarez Gil, M. J., Burgos Jiménez, J., \& Céspedes Lorente, J. J. (2001). An analysis of environmental management, organizational context and performance of Spanish hotels. Omega, 29, 457471.

Barras, R. (1986). Towards a theory of innovation in services. Research Policy, 15, 161173.
Baum, J. A. C., \& Mezias, J. S. (1992). Localized competition and organizational failure in the Manhattan hotel industry. Adminis trative Science Quarterly, 37, 564580.

Beaver, A. (1992). Hotel CRS. An overview. Tourism Management, 13(1), 1521.

Brouwer, E., \& Kleinknecht, A. (1997). Measuring the unmeasurable: a country's non R\&D expenditure on product and service innovation. Research Policy, 15(8), 12351242.

Buhalis, D. (1998). Strategic use of information technologies in the tourism industry. Tourism Management, 19(5), 409421.

Camisón, C. (2000). Strategic attitudes and information technologies in the hospitality business: an empirical analysis. International Journal of Hospitality Management, 19, 125143.

Carey, S., \& Gountas, Y. (1997). Tour operators and destination sustainability. Tourism Management, 18(7), 425431.

Cohen, W. M., \& Levin, R. C. (1989). Empirical studies of innovation and market structure. In R. Schmalensee, \& R. D. Willig (Eds.), Handbook of industrial organization. Amsterdam: Elsevier Science Publishers B.V.

Cohen, W. M., \& Levinthal, D. A. (1990). Absorptive capacity: a new perspective on learning and innovation. Administrative Science Quarterly, 35(1), 128152.

Conselleria d'Economia, Comerç i Indústria i Conselleria de Turisme. "La Despesa Turística", Palma.

Chung, W., \& Kalnins, A. (2001). Agglomeration effects and performance: a test of the Texas lodging industry. Strategic Management Journal, 22, 969988.

Darr, E., Argote, L., \& Epple, D. (1995). The acquisition, transfer and depreciation of knowledge in service organizations: productivity in franchises. Management Science, 41, 17501762.

Davies, B., \& Downward, P. (1996). The structure, conduct, performance paradigm as applied to the UK hotel industry. Tourism Economics, 2(2), 151158.

Deward, R. D., \& Dutton, J. E. (1986). The adoption of radical and incremental innovations: an empirical analysis. Management Science, 32(11), 14221433.

Ettlie, J. E., Bridges, W. P., \& O'keefe, R. D. (1984). Organization strategy and structural differences for radical versus incremental innovation. Management Science, 30(6), 682695.

Fernández, N., \& Marín, P. L. (1998). Market power and multimarket contact: some evidence from the Spanish hotel industry. The Journal of Industrial Economics, XLVI, 301315.

Font, X. (2002). Environmental certification in tourism and hospital ity: progress, process and prospects. Tourism Management, 23, 197205.

Gallouj, F., \& Winstein, O. (1997). Innovation in services. Research Policy, 26, 537556.

Go, F., Pine, R., \& Ricky, Y. (1994). Hong Kong: sustaining competitive advantage in Asia's hotel industry. Cornell Hotel \& Restaurant Administration Quarterly, 35(5), 5061.

Goes, J., \& Park, S. H. (1997). Interorganizational links and innovation: the case of hospital services. Academy of Management Journal, 40(3), 673696.

Gray, B. G., Matear, S. M., \& Matheson, P. K. (2000). Improving the performance of hospitality firms. International Journal of Comtem porary Hospitality Management, 12(3), 149155.

Griliches, Z. (1990). Patent statistics as economic indicators: a survey. Journal of Economic Literature, 28, 16611707.

Hassan, S. S. (2000). Determinants of market competitiveness in an environmentally sustainable tourism industry. Journal of Travel Research, 38(3), 239245.

Hipp, C., Tether, B. S., \& Miles, I. (2000). The incidence and effects of innovation in services: evidence from Germany. International Journal of Innovation Management, 4(4), 417453.

Hjalager, A. M. (2002). Repairing innovation defectiveness in tourism. Tourism Management, 23(5), 465474. 
Huybers, T., \& Bennett, J. (2000). Impact of the environment on holiday destination choices of prospective UK tourists: implica tions for Tropical North Queensland. Tourism Economics, 6(1), 2146.

Ingram, P. (1996). Organizational form as a solution to the problem of credible commitment: the evolution of naming strategies among US hotel chains, 1896 1980. Strategic Management Journal, 17, 8598.

Ingram, P., \& Baum, J. (1997). Chain affiliation and the failure of Manhattan hotels, 1898 1980. Administrative Science Quarterly, 42, 68102 .

Instituto de Estudios Turísticos, Secretaría General de Turismo. (2001). Evolución del Turismo en España Año 2000. Madrid: Ministerio de Comercio y Turismo.

Jones, P. (1999). Multi unit management in the hospitality industry: a late twentieth century problem. International Journal of Contem porary Hospitality Management, 11(4), 155164.

Kotas, R. (1982). The European hotel: methodology for analysis of financial operations and identification of appropriate business strategy. International Journal of Hospitality Management, 1(2), 7984.

Landau, R. (1991). How competitiveness can be achieved: fostering economic growth and productivity. In R. Landau (Ed.), Technol ogy and economics: papers commemorating Ralph Landau's service to the National Academy of Engineering. Washington: National Academy Press.

Marino, A. (2001). The tourist sector: public versus private the Italian and Spanish experience. Tourism Management, 22, 4348.

Medina Múñoz, R. D., Medina Múñoz, D. R., \& García Falcón, J. M. (2003). Understanding European tour operators' control on accommodation companies: an empirical evidence. Tourism Man agement, 24(2), 135147.

Moutinho, L., McDonagh, P., Peris, S. M., \& Bigné, E. (1995). The future development of the hotel sector: an international compar ison. International Journal of Contemporary Hospitality Manage ment, 7(4), 1015.

OECD. (1997). The measurement of scientific and technological activities. Proposed guidelines for collecting and interpreting technological innovation data, Oslo Manual. Paris: OECD.

Okumus, F., \& Hemmington, N. (1998). Management of the change process in hotel companies: an investigation at unit level. Hospitality Management, 17, 363374.
Olsen, M. D., \& Connolly, D. J. (1999). Antecedents of technological change in the hospitality industry. Tourism Analysis, 4, 2946.

Otto, J. E., \& Ritchie, J. R. B. (1996). The service experience in tourism. Tourism Management, 17(3), 165174.

Pavitt, K. (1984). Sectoral patterns of technical change: towards a taxonomy and a theory. Research Policy, 13, 343373.

Pennings, J. M., \& Harianto, F. (1992). The diffusion of technological innovation in the commercial banking industry. Strategic Manage ment Journal, 13(1), 2946.

Pine, R. (1992). Technology transfer in the hotel industry. International Journal of Hospitality Management, 11(1), 322.

Saleh, F., \& Ryan, C. (1992). Client perceptions of hotels. A multi attribute approach. Tourism Management, 13(2), 163168.

Sangster, A. (2001). The importance of technology in the hotel industry. Travel \& Tourism, 3, 4356.

Sheldon, P. J. (1983). The impact of technology on the hotel industry. Tourism Management, 4(4), 269278.

Sirilli, G., \& Evangelista, R. (1998). Technological innovation in services and manufacturing: results from Italian surveys. Research Policy(27), 881899.

Sundbo, J. (1997). Management of innovation in services. Service Industries Journal, 17(3), 432455.

Sundbo, J., \& Gallouj, F. (2000). Innovation as a loosely coupled system in services. International Journal of Service Technologies and Management, 1(1), 1536.

Tisdell, C. (Ed.) (2000). The Economics of Tourism. Massachussets: Edward Elgar Publishing Limited.

Van der Aa, W., \& Elfring, T. (2002). Realizing innovation in services. Scandinavian Journal of Management, 18, 155171.

Wei, S., Ruys, H. F., van Hoof, H. B., \& Combrink, T. E. (2001). Uses of the Internet in the global hotel industry. Journal of Business Research, 54, 235241.

World Tourism Organization (WTO). (1999). Tourism market trends. Madrid, Spain.

\section{Further reading}

Instituto Nacional de Estadística. (1998 2000). Contabilidad Regional. 